\title{
Recent Literature on Dance and Identity
}

Janinka Greenwood's Griffin University doctoral thesis is titled Journeys into a Third Space A study of how theatre enables us to interpret the emergent space between cultures. This is a summary of thinking on biculturalism put together with an idea of a third space and, on this basis, an interpretation of dance and dance education in Panguru and elsewhere in Northland.

This thesis is considered first in this discussion as it is the oldest and comes from an earlier time. At the same time it is a very good review of the arts, the thinking and mood of the late eighties and early nineties as well as very sound review of the literature.

Greenwood talks of Arnold Wilson and Don Selwyn, of Ranginui Walker and Garfield Johnson, educators and polemicists of the ideology known as biculturalism. Writing for an Australia audience she contrasts biculturalism with multiculturalism. At the same time her subject of study, Te Mauri o Pakeaka is an educational arts programme that happened in Panguru and elsewhere in the North, an area where the Treaty of Waitangi is very important and where there is often only two cultures, Maori and Pakeha in the form of white farmers and storekeepers involved.

This allowed for a clear statement and reading of biculturalism and then a Third Cultural Space, an emergent cultural space, the space between these two well defined cultures Maori and Pakeha.

Two other books from that time also come from Auckland and these are Francis Pound's The Space Between of 1994 and 
Martin Blythe's Naming the other-images of the Maori in New Zealand film and television. These are concerned with urban and national communities.

A full reading of all three books is recommended along with Rangi Panoho in Headlands in 1992. At the same time the various articles in this area in Ilusions by authors like Pound and Blythe not mentioned by her might be read to gather a fuller understanding of writing in this area.

At the same time Greenwood brings up local writing, especially that of Sebastian Black and others at Auckland University not mentioned as often as they might be elsewhere.

Greenwood is talking about cultural understandings, educational policies and practices and what she sees as new formulations of aesthetic and semiotic frameworks. There is a lot of learning about theatre involved and it is interesting and refreshing to read about 'process drama' and 'playwright theatre', about 'crystallization' applied, inter alia to the arts and arts education in New Zealand schools.

Greenwood also talks about 'frame'. As well as the use of frame in teaching and exploring theatre and drama the thesis is about the frame of biculturalism. As she says in her conclusion;

'By the time Pakeaka was terminated, biculturalism had become a buzz-word among Pakeha liberals and was being critiqued by Maori activists as a mask for neo-colonialism'.

As she considers her subject Greenwod talks variously of a sacred space and of 'hot spots in the data', contradictions and dissonances.

Her definition of Pakeha is as designating non- Maori New Zealand identity.

The thesis is interesting in its historical recollection, of things like Peter Boag's distinction between 'brownies' and 'pinkies'.

Greenwood lays a sound foundation of reading for anyone interested in things on stage; Schechner, Heathcote and others. At the same time she provides an important and 
interesting spread of reading with references to anthropologists like Geertz (1988).

And Greenwod's report on a production of the Maui cycle could be read alongside the reflections of Tanemahuta Gray some a decade or two later (cf Koowhiti, tekaharoa.com 2012) to give a good understanding of how the myth cycle might be presented and its meanings.

Greenwood also reflects teaching styles and preferences of the day lining up Freire with the local indigenous theorists of Graham and Linda Smith and theorists of the theatre and drama like Boal and his Theatre of the Oppressed of 1979. There is a mild strain of psychodrama in the thesis although Moreno is not heavily featured. Having the teacher as colearner' and 'providing the student with the mantle of expert' are key points of reference.

Greenwood speaks of sacred space along with social coinage. The proto-drama of the work as a whole is a dramatic reframing of the existing social order, a rehearsal for change in the social domain. Coinage is also seen as an appropriate metaphor for the West with its emphasis on currency.

Greenwood refers to the work of Maori Marsden to the effect that the material and the spiritual exist side by side.

With these thoughts as well as the business of co-teaching and co-learning in mind Greenwood says;

'As well as the invitation to enter a sacred space, Pakeaka is a confrontation with what it means in empirical terms for the education system to serve the needs of Maori.'

And again;

'What is claimed in the Pakeaka proto-drama is mana motuhake, right of control over one's decision making or, to put it another way, a distinct voice.'

There are also the specifics of teaching in the North, especially the issue of teaching drama with and as an acknowledgement of culture. Greenwood refers to the people from Dargaville with their balalaikas, the Dalmatian influence, along with those from places like Pangaru with their koauau. 
Greenwood brings us back to biculturalsim with a look at 'two chair' work in psychodrama and a series of references to the way Jean Genet sees the other in plays like The Balcony, the way that one sees oneself in the other, the idea of a dramatic mirror.

This is a powerful dramatic tool that creates a split and then the eventual opportunity for healing and Greenwood leans into biculturalism with this idea along the way bringing in Freire and Boal. The splitting of monovision germinates the potency for change in the oppressor.

While there is discomfort for the oppressor there might be growth for the oppressed. She refers to Greenwood 1984 for a discussion of this splitting and healing process.

Greenwood makes the point that over ten years of its operation Pakeaka did not have a static form but some premises did remain constant.

Things are brought up short by the Hawke Report of 1989 and the fiscal cuts and rationalisations made by the Education Department at that time.

Greenwood's discussion of Pakeaka considers role and self, experiential learning and culture, tradition, identity and borrowing as well as drama, safety, learning and risk.

The two ideas of sacred space and social coinage are persevered with. Biculturalism rather than blending is the order preferred by Greenwood and her informants as well as in the writing she follows such as Orange, Durie, Walker and others. The general idea is that Pakeha are looking at Maori as the 'unexpected stranger' in their midst.

Following Davis (1994) Greenwood notes that femaleness is marked and maleness is not. There is a consideration of Michael King's writings on being Pakeha. As these readings are presented Greenwood affirms the active and influential power of theatre and notes that it is not simply involuntary and passively reflective.

Greenwood talks about Boal, Soyinka and Scechner as she considers ritual, Moreno and Landy with regard to drama 
therapy, Turner and Handelman regarding social drama and talks about Brecht and others as well. She quotes Schechner (1993:20) to speak of four great spheres of performance; entertainment, healing, education and ritualising. These are 'at play with one another'.

Greenwood says;

'Western theatre presumes its origins in ritual and non western theatre is often described in terms of its continuing connection to ritual.'

Ritual can be seen as a balancing of social controls and as an alignment of humans in the cosmic order. Greenwood quotes Soyinka (1976: 38-41) and Turner (1988:25) talking about liminality and limbo as a threshold between secular and sacred.

Greenwood provides a thorough- going investigation of this literature to see how it applies to biculturalism. She quotes Schechler (1993) to the effect that what will happen is;

'either the re-integration of the disturbed social group or the recognition and legitimation of the irreparable schism'

Greenwood akso says;

The multifaceted, collaborative approach to pedagogy offered by drama has resonances with the issues raised by contemporary Maori educational theorists.'

And goes on to talk about a whanau or whole class approach or a poutama or staircasing. She again makes the connection between Maori theorists of her day and Boal and the theatre of the Oppressed and Freire as she sees theatre as a liberatory process.

Greenwood talks of Landy's taxonomy of roles and suggests that the use of roles has potential for healing through drama.

Greenwood talks of frames and quotes Zarilli (1990:46) to say that the Western emphasis on mimesis and persona is not usefully transported to other cultures. Greenwood talks of consensus and confrontation. 
In her discussion of Stuart Devenie Greenwood talks of 'Pakeha gatekeepers'. Devenie in an interview with her talks about how New Zealand actors are trained to do Americanvoice and body.

There is the idea of the cultural space between Maori and Pakeha as being 'terribly important to the integrity of both parts'. The idea is that this space between offers great joy, pain and danger.

Greenwood says; 'Like many others Don (Selwyn) considers that if we sort out the bicultural nature of our society "then the multiculturalism will take care of itself" '.

There seems to be a fear of the melting pot;

The understanding of biculturalism offered by Pakeaka is categorically not one of cultural blending.'

Regarding the workshops in Panguru 'it is Maori that is the unmarked norm. It is Pakeha values and practices that are characterised for difference.'

A final thought from Greenwood that stays in the mind is; 'Biculturalism is not a fixed space to which one might arrive. but rather a space for improvisation'.

The next doctoral thesis is that of Mark Hamilton from Canterbury University. This is Martial Dance Theatre:

A Comparative Study of Torotoro Urban Māori Dance Crew (New Zealand) \& Samudra Performing Arts (India)

This is an excellent discussion of the contribution made by Mika and Torotoro and the challenges faced by them. The discussion of haka and bodily display makes this thesis striking and in many respects original.

The thesis looks at 'martial arts theatre's masculinist potential and its contribution to the intercultural negotiation of identities'.

Torotoro was a dance company that operated from 2000 to 2009. It started with Mika HAKA in 2001 in Auckland.

Who was or is Mika? Hamilton says;

The ironic distance evident in Mika's self-presentation might be considered a consequence of him growing up as a 
flamboyant gay Māori boy in a suburban Pākehā family.Mika was adopted at birth by a Pākehā couple who lived in a predominantly Pākehā town.

Till he was eighteen his principle contact with Māori culture was through representations of Māori targeted at nonMāori viewers - materials comparable to the Adidas advert discussed in the thesis' introduction.12 Mika has not visited his birth father's marae and he lives and works without a specific tribal affiliation. Mika stands outside of usual Māori hierarchies and has no elders to whom he is obliged to defer when creating his representations of Māori culture. This made him the sole authority under which Torotoro worked when performing Mika HAKA.

On the one hand, Mika's adoption separated him from marae life and tribal culture, but at the same time his dark skin invited people to identify him as Māori and not Pākehā. In addition, his homosexuality further distanced him from the heteronormative orders of both Māori and Pākehā society. Mika's persona in Mika HAKA was the product of a twentyyear performing career that staged, and largely celebrated, his experiences of not belonging and of always being the Other. Mika HAKA invited Torotoro to join Mika in this project, and the creation of stage personae similarly keyed.

Mika's stage persona queers both his gender and ethnicity. He presents male and female, and Māori and non-Māori attributes.'

Who were in Torotoro?

'Certainly, the company's processes of casting and performance were not guided by the particularities of tribal affiliation which Papesch identifies as the factor that authenticates kapa haka as a valid expression of Māori identity (Papesch 2006:37). Torotoro operated without tribal affiliation, uniting simply as 'Māori'.'

Hamilton is interested in looking closely at martial arts;

'Indeed, the examples of contemporary martial dance theatre that this thesis explores might more accurately be 
called 'martial arts dance theatre'. In part, performers in these productions present 'as' dance theatre the codified and ritualised movements that create the drills and displays intrinsic to their hereditary martial arts. This invites consideration of the ways in which these apparently combative disciplines might be considered always already aesthetic and expressive forms, and one task of this thesis is to elaborate new understandings of what the 'martial arts' are.'

In 'Hongi' Torotoro shifts back and forth between martial movements that prevent a challenge to their audience and dance movements that invite and welcome their gaze. Hamilton sees this as both confrontational and inviting;

'The dancers' minimal clothing might also be seen to contribute to the confrontational-inviting tone of their performance, for it displays their well-toned bodies in a way that might be seen underline their martial readiness but also to offer a potentially erotic spectacle. What is more, when a difference of ethnicity, or race, distinguishes the companies from their audiences this might be seen to contribute additional tensions and ambiguities to the bodily spectacle created in their martial dance theatre.'

There are juxtapositions of wero and haka and 'the globalised form of breakdance'.

The eye contact in Torotoro's interaction with their audience seems at times imperious and at times compliant. Hamilton refers to Grotowski and Zavilli, to an 'aesthetic inner bodymind'. This compares with Mazer's discussion, considered below, of the rehearsals of Kapa Haka where she refers to a memorialisation of Maori matters, internalisation of identity through dance or as seen in dance.

There are some extremely interesting things in this thesis such as the discussion of space, audience and internalisation;

'Torotoro and Samudra's martial dance theatre makes theatrical performance from the movements of the intimidation displays and pattern practices that are intrinsic to their Māori and Malayā i martial arts. Training in such activities initially 
requires practitioners to master combative movements in the fixed order and rhythmic and spatial arrangements prescribed by their teachers. Most significantly, like dance theatre performances, these intimidation displays and pattern practices are drilled while facing an empty space - a space later occupied in ritualised contexts and theatrical settings by witnesses and audiences with varying expertise about Māori and Malayāḷ martial arts. As such - advancing KlensBigman's suggestion that kata are dramatic scenaria Torotoro and Samudra's incorporation of intimidation displays and pattern practices in their martial dance theatre creates martial 'soliloquies'.'

And then there are the possible reasons for the appeal of the show to overseas audiences outside of erotic or martial considerations;

'Participating in Mika HAKA can be seen to have engaged Torotoro in a process of self-exoticisation, because the allure of their difference from non-Māori audiences was the principal focus of their martial dance theatre. Indeed, their martial dance theatre might be seen as the vehicle through which Mika endeavoured to teach them his use of self-exoticising and self-eroticising performance as a means of self-empowerment. In particular, Mika can be seen to have encouraged Torotoro to indulge Eurocentric erotic fantasies about exotic natives.'

Hamilton brings a good mix of local and international writing to bear on his subject;

In Pacific Performances Balme speaks of how traditional performance - especially that created for presentation to foreign audiences - often engages in a temporal 'freezing' which suggests that quintessence of the culture being staged is located in the past and not the present. Balme connects this phenomena to James Clifford's "salvage paradigm," through which certain schools of ethnography "desire to rescue 'authenticity' out of destructive historical change" (Balme 2007:186). Balme also considers how such cultural freezing might be seen as part of the 'invention of tradition': 
According to this thesis, varied in different nuances by MacCannell, Culler, Urry, and Frow, the condition of alienation constitutive of modernity [...] has bred as its antithesis the 'invention of tradition' and the increasing priority placed on authenticity in objects, peoples and places apparently located outside the realm of modernity (Balme 2007:187).'

We are considering the equation or otherwise of contemporary society and dance. Hamilton points out that in When the Body Becomes All Eyes Zavilli notes that Kalarippayattu achieved its contemporary totemic value during the founding of the modern state of Kerala. Hamilton compares this to references to the writing of King and Walker about Te Puea and Ngata in the 1930s and talks about the connections between contemporary consciousness and performance.

Coming back to space, stage and audience;

'When the creation of Mika HAKA began he was performing sexually provocative solo cabaret at arts festivals in Australasia and the UK. Mika HAKA targeted the popular British market in a bid to change Mika's international performance career from that of a queer artist addressing arthouse audiences to a main house performer addressing a general audience.'

Hamilton is talking about a meshing of attractions and support for Mika from a variety of sources;

'A representative of the late Māori Queen attended the debut of Mika HAKA, and The Ministries of Social Development and Māori Development supported Torotoro's development. The UK tours were funded by Trade New Zealand - a government enterprise agency.performance might be seen to have created a work with an interracial exotic erotic appeal.

MikaHAKA secured domestic support for its revised image of New Zealand's bicultural identity while also engaging Eurocentric fantasies about native men. What might this dual 
appeal suggest about the persistence of imperialist values in New Zealand and the UK?'

Hamilton refers to Brendon Hokowhitu and to Irving Goffman as he considers athletes and dancers, notably Goffman's dancers and boxers and their ambiguities. This argument goes that boxers and tennis players do bodily display only on an incidental basis while dancers do it on an intentional basis. This may be a tad disingenuous when it comes to people like Sonny Bill Williams, the rugby star with the great body but in general the argument holds; sports people have to be good at their specific tasks regardless of looks.

Hamilton sees wero and haka as in between and agues that Mika frames wero and haka in terms of bodily display, as something more than intimidation and more like dancing than boxing.

On gender and performance;

'It is pertinent here to acknowledge that this thesis' focus on male dancers perpetuates the bias observed in contemporary martial dance theatre productions. Women perform in the genre, but they are outnumbered by the men and have limited roles: the genre's focus is on the men's performance. Mika HAKA largely duplicates the gender roles of kapa haka. During haka the women give centre stage to the men, but they are prominent in the lyrical action songs and poi items (dances with balls on string). When the company dances in unison the movement vocabulary is based on wero, haka and breaking, all idioms conventionally gendered as masculine. In search of commercial success Mika cast women in Mika HAKA to accommodate the gaze of male heterosexual audience members, but significantly the production features no male-female partner dances. 2012: 49'

And then;

'Moreover, the productions' potential to affirm gender norms is destabilised when the women step aside and leave the men centre stage. The heterosexual male erotic gaze their 
presence invites may potentially fall on the men- highlighting the homoerotic potential of their performance, and the potential slippage from homosocial identification to homosexual desire that is present in martial dance theatre. 2012: 53'

Intentionality runs right through all discussions of identity considered here. One thinks of Mazer's earthquake function discussed below. Hamilton takes the reader from dance to race, to Butler, Lee and identity;

'Butler's theorising about performativity has informed analysis of ethnic and racial identity. In the 1999 preface to her book Gender Trouble: Feminism and the Subversion of Identity Butler says:;

'the question to ask is not whether the theory of performativity is transposable to race, but what happens to the theory of performativity when it tries to come to grips with race (Butler 1999:xvi).

In her 2001 journal article "Bodies, Revolutions, and Magic: Cultural Nationalism and Racial Fetishism" Josephine Lee adapts Butler's theorising of gender as the legacy of sedimented acts to explore race as a comparable performative construct. Lee says:

The particular ways in which we perceive, interpret, and value racial difference in the United States today can be understood as a kind of 'performance' that takes its significance from not one but, in fact, many layers of social meaning, that history has deposited on bodies (Lee 2001:72).'

Hamilton seems to be asking whether such representation of wero and haka renders it impotent and nostalgic.

In a central part of his argument Hamilton refers to Goffman's idea of keying. The example here is wero or haka where, as Hamilton sees it there is a rekeying involved. When wero is performed overseas there is a 'keying that is tangential to this history of keying'.

And then; 
'Mika HAKA is a rekeying of the theatrical staging of the wero and haka presented in kapa haka. Whereas kapa haka is seen to stage and preserve inherited Māori culture for Māori benefit, Mika HAKA maximises on the appeal of these martial practices for non-Māori Western audiences. In this way, Mika HAKA constructs sensational images of Māori men by elaborating upon three largely disavowed aspects of kapa haka: the presentation of Māori performers as Other to New Zealand's European settlers; the use of cultural syncretism to create a performance that communicates across this stated cultural divide (and cultural differences within Māori society today); and the potentially (homo)erotic display of the male Māori body that is created by the haka. By exaggerating these aspects, Mika HAKA might be seen to expose how this traditional performance practice - and the martial masculinity it promotes - is a form of exotic-erotic mimetic capital shaped through intercultural interactions, rather than a spontaneous and unchanging expression of Māori indigenous identity.'

Where there is instability and indeterminacy there might be 'serial rekeying'. Following Goffman (1975: 159) the idea is that once keyed then rekeying might follow and 'each subsequent rekeying would seem to require less work'. And then there is the 'negative experience' when you can't find the key for what you are doing.

Hamilton then walks through a tour of Huizinga (1949) and play, Bateson (1972) and frames and writers like Schechner (1993) who prefers the idea of nets rather than frames.

Hamilton asks some good questions. How do we give frames, keys or nets to Mika and Torororo? Best refers somewhere to play fighting and one wonders about distinctions between real fighting, play fighting and ritual. The 'He tama, Tu tama' skit in concert parties of the sixties and seventies where people did hand slapping, stop-start routines seemed to me, at least to be part o a light heated or light relief type of theatre. I have never seen that 'camped up' but it was a 
feature of concert party activity where irreverence and asides were expected.

Anyhow, coming back to this thesis it seems that if you play with keys or frames long enough then you are playing with play itself and Hamilton turns again to Goffman (1975:57) on this.

Is it like wrestling or boxing on television where once you start to make it entertainment the process goes on, more and more quickly?

Hamilton talks about fictional bites in martial arts after Bateson 1972:182).

There is a gap between action and intention and Hamilton says the "participants deliberately present the idealised ethnically specific masculinities that wero and haka might be seen to sustain. And so we have a 'genre formed by the perception of the audience rather than the action of the performers'.

Hamilton then takes us through a discussion of the identity of the self and the consideration of Butler here is fascinating; 'self as arising through the performance construction of gender'. The idea here is that gender is constructed through repetitive performance.

At this point a wider set of questions occur about Hamilton's work. Quite rightly Hamilton is talking about identity and dance. That is his thesis topic. But it brings things up short to ask whether identity is always found through the body. In the wero and haka examples that Hamilton is using this all goes back to two traditions both involving kapa haka. One is the tradition of performing for tourists coming out of Rotorua and the other is the tradition starting with Ngata and Te Puea of retaining their reo and tikanga through concert party work involving tours and participation in major state events like welcoming dignitaries.

But since the late nineties there has been the Maori Radio and then television as ways to learn these things. There are books. There are Maori language classes. There is the Kohanga 
Reo. But for a period say from the 1930s until the late eighties dance and dance related activity, kapa haka wero, powhiri and the like were major vehicles of cultural and language transmission as they still are even though new vehicles like radio, television, the internet, books and the classroom have appeared.

Dance as a key or critical vehicle for cultural retention in the absence of other strategies is not really considered by Hamilton or other writers in the set of readings discussed. I learnt Maori from people in the bush who did not do a lot of kapa haka until cultural festivals started in the early 1970s and even then some of the people I knew were a bit shy of it all. That was an exceptional situation though and most people wanting to learn Maori were victims of language loss with only the world of dance and performance to turn to through Kapa Haka and hui.

There is an equation here of body and language, body and culture. People did not lean the reo by sitting at home and writing letters, they gathered in groups and got to know their language by singing it, chanting it and writing songs and chants for their groups to take on tour where they would hear others who had been through similar processes.

So somehow in Aotearoa there had been a fusion of body, dance, group activity, language and culture and Mika and Torotoro performed in this context.

And as part of this there are issues of vocabulary and Hamilton picks up on this;

'In his monograph Haka! The Dance of a Noble People Tìmoti Kāretu (quoting haka exponents Ngāpō Wehi and Kīngi İhaka) states:

Without the word there is no haka and this is the one aspect of contemporary haka that needs attention [...] The language, which is fundamental to the issue, is becoming peripheral while the actions and movements, the peripheral elements, are becoming the prime focus (Kāretu 1993:83-4). 
Kāretu's proposition is somewhat challenged by Nathan Mathews article "The Physicality of Maori Message Transmission," which offers a detailed examination of the extensive movement vocabulary of haka and its expressive value (Mathews 2003). He argues that physicality should be attributed greater importance in the analysis of how haka communicates. 2012: 86'

Group learning in through oral interaction developed at the same time as Kohanga Reo in the 1970s with the rakau method.

Coming back to Mika and Torotoro, Hamilton suggests that their productions rekey wero and haka in ways that emphasise their aesthetic and theatrical dimensions and their presentation of images of ideal men'.

Hamilton quotes Dyer as he considers 'doing' and 'looking' as masculine and 'displaying' and 'being seen' as feminine.

This is an analysis that stretches back to Berger and compares with Laura Mulvey's work of 1989.

Importantly Hamilton notes the complexities in this as he quotes Thomas' work of 1993 suggesting that men too are objectified through the gaze. Hamilton asks the question how might their 'doing' of martial actions have contained notions of the male dancer as a passive figure on display?'

Hamilton follows a suggestion from Burt that male dancers disturb western gender norms. He refers to heteronormative Eurocentric masculinity and to drawing the homosocial back into the realm of desire.

And then there is the use of break dance or breaking. There is the idea of an international alliance of non-white people for Maori and Pacifika people through breaking.

Hamilton quotes Balme and Grenblatt to the effect that there is always something familiar in the exotic (otherwise it would be too far away to register) and applies the idea of rekeying and new signs to that. There a tension between the too exotic ad the too easy. Balme talks of things being non- 
decodable and sets out a contrast between alterity and familiarity, savagery and aesthetics.

Along with this Hamiton refers to Torgovnick (1990:8) in regard to 'primitivist tropes'. Through these discussions the notions of camp and of flirtation are interspersed.

In an interesting discussion Hamiton compares the role of the kaea or leader of the wero and haka and the role of the bboy of the breaking group in Torotoro's work.

There is something of a contradiction in the highly masculine actor in haka and wero and the idea of a female primitivist world following Torgovnick (1997:14). Are things already rekeyed, already queered even before Mika sets out his work?

Torgovnick (1990: 18) sets out a contrast between the dangerous and violent and the mystical and spiritual in the primitivist world. Hamilton puts this as follows;

'In the UK Mika HAKA and The Sound of Silence became disconnected from their homeland cultures. They became, to a degree, elemental spectacles of foreign male bodies. These productions in such contexts evoke essentialist primitivist tropes about the exotic figure of the 'native' man. The companies' might be seen to indulge or subvert the imperialism implicit in these imaginings.'

Throughout this fascinating thesis Hamilton drops a number of questions or, rather, a lot of questions occur to the reader. Does Kapa Haka perpetuate indigeneity?

Hamilton discusses Lee's fetishes and makes one think about wero and haka as exported.

There is the assumption in the thesis that that $\mathrm{Te}$ Matatini, compared to other activities is not commercial. But it is a big operation benefitting the host region involving Maori radio and television.

There are the two histories, high and low of Rotorua and Ngaruawahia regarding kapa haka. Commodificatpon obviously occurs in Rotorua but there are other considerations 
such as the survival of culture and language. The contrast between Mika and Matatini is familiar.

With Mika HAKA is there something of a low local culture working as high culture in Edinburgh?

There is Tania Kopytko's Breakdance as an identity marker in New Zealand and she suggests (1986:26) breakdance is a 'readily available connection to an international Black identity'.

Mika saw breaking as a way to break up traditional haka and wero for the Edinburgh audience. Breaking functioned as a cool bridge with street cred. And then there is a quote from Banes;

'Banes says breaking involves: "using your body to publicly inscribe your identity on the surface of the city, to flaunt a unique personal style within a conversational format" (Banes 2004:14)' 2012: 53

Hamilton proceeds from Banes to Balme and other theorists;

'My analysis of Mika HAKA and The Sound of Silence asks how their rekeying of martial arts and dance forms, in particular in the UK, might create a sexualisation and commodification of the identities articulated by these corporeal styles. In his introduction to Looking Out: Perspectives on Dance and Criticism in a Multicultural World David Gere proposes the need for examination of "the aesthetics of transfer" - that is, the implications of the presentation of nonWestern dance on proscenium theatre stages in the West. In his book Pacific Performances: Theatricality and Cross-Cultural Encounters in the South Seas,

Christopher Balme's analysis of intercultural performance determines some of the implications (also noted by Lee) involved in such "cross-cultural contacts" (Balme 2007:7).'

And on to primitivism where things are;

'exempt "from the repression of sexuality and control of aggression" that constrain Western life (Torgovnick 1990:228). Moreover, the companies' martial dance theatre interact with 
tropes that, says Torgovnick in her book Primitive Passions: Men, Women, and the Quest for Ecstasy, code the primitive as the feminine collective counterpart to masculine individualistic civilisation (Torgovnick 1997:14)? Their performances emphasise the "double valance" that identifies the primitive as "both violent and spiritual" (Torgovnick 1997:14).'

It is probably important to consider eros and money at some stage. Hamilton only does this in passing but obviously Mika is in the zone of the male stripper, the world of clubs, pole dancers and so on;

'Furthermore, Torotoro's performance in Mika HAKA has a pronounced erotic potential, in that the dancers are deliberately costumed to display their athletic bodies in a titillating way, and they do so along side Mika's own overtly sexualised and queer performance. Torotoro's martial dance theatre might be seen to theatricalise wero, haka and breaking to create a sexualised performance with a commercial value.'

And thenthere is the Other;

'Contemporary Māori culture necessarily negotiates with the ethnically (and racially) determined Othering that the bicultural structure of New Zealand sustains.'

And on to identity;

'As such, Māori identity is necessarily anchored to the period when European settlement began in particular. As such, though the kapa haka that Te Matatini promotes could be seen to promote a nativist Māori cause, it could also be seen to perpetuate notions of indigeneity that are in keeping with the neocolonial agenda of New Zealand's government. Paradoxically, however, perhaps in doing so kapa haka successfully contributes to the Māori participation in New Zealand's political discourse, in as much that Māori find their strongest voice when addressing the Pākehā establishment through a historicised identity.'

We might make connections between Mika and the sapeurthe dress conscious male out of Brazzaville- or the French flaneur or Tame Iti and his dress in court as well as his dance 
activity. Is the significance of Mika a look, an air, a 'dress' more than a matter of, say, wero, haka and breaking?

There is a home and away aspect to the thesis where Hamilton considers the knowing local audience and the unknowing audience or the audience that okows something else. Tourism in its various shades runs through this. The audience in Edinburgh is as foreign as the tourists in Rotorua.

Hamilton draws on Shennan (1984:5) to speak of Auguste de Sainson's visit to New Zealand in the 1820s when he compared haka to a lovers' contest and it was unclear to him whether the performers were celebrating victory or love.

Hamlton refers to Soomon-Godeau and talks about an ephebe, an ambisexual figure. Moore (1988:33 talks about the' codification of men via gay discourse enables a female erotic gaze. The phrase 'ephebic cohort' rings true.

Hamilton draws a contrast between the historicized local tradition of haka and wero and suggests a vertical axis for this as compared to a horizontal axis for breaking stretching to a contemporary global situation.

Hamilton turns to Belich's four fold classification of Maori as Red, Brown, Black or White (2006:370). He talks about Papesch's combination of Kapa Haka and tribal identity.

Through these and his own lenses Hamilton, at the end, sees Mika as exploring intercultural and intergender identity, playing to European fantasies of native ephebes. He suggests Kapa Haka rekeys a threat into a thrill. Mika is living in a 'space of otherness'.

The third thesis to be discussed is not directly about dance but is it about identity. Emma West's Manu is my Homegirl: Navigating the ethnic identity of the Maori adoptee is a Master of Philosophy thesis from Te Ara Poutama, AUT.

The great value of this thesis is that it challenges a range of categories including, Maori, Pakeha and biculturalism. A person shifts from one identity or construction of such, to another depending on the context. 
It is important to note that Emma West is talking about a fairly small range of people, those involved in closed adoption as children. At the same time her thesis is a brilliant exposition of strategies to do with identity in Aotearoa, strategies that seem to this reviewer to be applicable or at least worth considering in terms of the subjects of other writers discussed here.

Like Billy T James, Kiri Te Kanawa and Mika Emma West is herself an adoptee. As described by Hamilton above Mika's situation seems to have been like Emma's while Billy and Kiri were adopted within Maori society.

Using an interview process West looks at how adoptees use or do not use such things as te reo, tikanga and kapa haka to find and express identity and how they perform in everyday life. West's subjects may be contrasted with Grenwood's I that where identities might be clearly defined in Panguru this is not the case for West's group. Having said that some of the latter group do come from the countryside.

One of the refreshing aspects of this thesis is the combination of Social Psychology and Sociology. This means references to Liu et alia (2005) for example, and shows the value of working in a cross disciplinary context at the AUT. West uses this wider disciplinary reach $t$ to break new ground. As always with something original there is the sense that something previously familiar but just out of grasp has been explained in such a way as to allow new questions.

Oe such new question might be what happens where tikanga is adopted in perfprmance work and in ritual by nonMaori? In her paper discussed below Mazer raises such a situation in a coda to her paper where she describes a university function after the Christchurch earthquake. The functions follows tinaga and te reo is used but here are few Maori present. This example, like the discussion of Suzie Cato later in this collection might be better understood after a reading of West's thesis. People have been adopted across 
ethic groups and so, in Aotearoa- New Zealand, have rituals and language all with an effect on identity and its expression.

But the new question most often asked by Emma Wes herself is to do with the world of identies experienced by the Maori person who has grown up in a closed adoption. How is a sense of self found and maintained in the arts and in language and in everyday life?

At this point Hamilton's work on Mika might be econsidered. Is the reworking of matial arts as bodily display by Mika and Torotoro an exploration of identity?,Is it a reaction to ascription or prescription of identity? Is it's a grounding of such questions in the body and dance? And is such grounding in the body to do with the way identity has been developed I this country through face to face interaction and bodily interaction as in kapa haka?

The questions that Ryan Hartigan who is dicussed below asks about the haka and its international significance might also be related to West's hesis but the latter is, generaly speaking, about the New Zealand context.

Some reviews of literature by West yield very good results and one example of this would be the application of Verrier's thesis of the primal wound (Verrier 1993). Given that such citations are made against the general background of the standard texts like Berger and Luckman (1966) and a consideration of the research on Maori identity such as work by Durie (1995) there is a sound, critical and well directed review of literature.

It is interesting that the idea of 'navigating' is used in the Whanau Ora context for example. At the same time the sense of navigation applies across the literature discussed here although West is using it in a much more extensive way so that instead of asuming that parties are secure in their cultural identity the asssumtion seems to be that just In case that is not so there might often be a need for reflection and then navigation, sometimes in an instant.. 
The very idea that people need to navigate an identity is important and possibly under researched. Is the navigato process itself part of the identity?

There is other work on identity that is not referenced by West. One thinks of Veronica Tawhai's work on rawaho (Tawhai 2010), people who do not have direct whakapapa links to the area in which they reside and who are rendered invisible in certain respects, say when it comes to making submissions on the environment. Tangata whenua come first. The value in considering Tawhai's work here might be that it shows how identity questions exist for Maori who have adopted new places to live and for those Maori who who there first and who adopted others into their territory. There is a complex of identity, genealogy, residence and other matters that stretches across the country and is, in effect, he context for West's research as it is formost of the other work discussed here.

Emma West's thesis makes a number of challenges. At one stage the student suggests that the term Maori is used as a weapon and might well be reviewed in its uses. While West does not refer to it there might be a cross reference to Cheryl Te Waerea Smith's idea of a 'cultural cage' here (Smith in Murphy ed 1993)). At other points she questions biculturalism and as she explores the idea of navigation there is a sense in which categories like Maori and Pakeha are not set in stone. It depends on the intentions of the actor. The self is multilayered and people present in different ways as they navigate,

While there is mention of Alcoff and Mendieta (2003) and a discussion of modern identities in this thesis there might be a commentary to follow looking at the way key identities shift over time. Emma West looks at the shifts in identity in the latter half of the twentieth Century and the early part of this one with respect to distinctions internal to the country of Maori and Pakeha and in between. When and how people became preoccupied with ethnic identities over time is an important aspect to be researched, one that Emma West's thesis evokes. The work of Franz Fanon (1963) on the 
psychological aspects of decolonisation in North Africa comes to mind.

West's work avoids a binary or two sided approach and looks to creative solutions to any given social situation. The thesis is referred to again in discussion of work at Ora Gallery in Wellington later in this collection.

The first article to be considered is by Ryan Hartigan, Embarrassing Time, Performing Disunity Rugby, the haka, and Aotearoa-New Zealand in the United Kingdom appeared in Performance Research (Vol 16 No 2 37:44). Hartigan's work takes us to a consideration of the haka and this article is refreshing. So many new threads are picked up and there is a good perspective offered on haka and its significance outside Aotearoa.

Hartigan refers to Homi Bhapha (1944:142) regarding the 'ambivalent temporalities of the nation-space'. He also refers to Warner's 'counterpublic' (Warner 2002:56).

And he quotes Elizabeth Freeman saying 'the colonial state intervened early into indigenous temporality'. Hartigan looks at Freeman's idea of chronopolitics and discusses modalities of time referring to the colonial calendar and the working week.

The events concerned range from the 1988 to the 2008 tours of New Zealand rugby teams to th United Kingdom or parts thereof.

The starting point of Hartigan's argument is the way rugby writers, usually from outside of New Zealand, consider the haka, the writers discussed like Keating often deriding it. This gives rise to the feeling of embarrassment set out by Hartigan, a feeling with several hues.

Hartigan like Hamilton refers to queer theory (Hemmings 2005:549). This is in regard to 'native powers of shame'. There is not a reference to the concept of whakamaa or a cross referencing to indigenous notions of shame but Hartigan throws open all sorts of splits and wounds and asks readers, at least this reader to consider all kinds of healing to take a perspective from Greenwood. 
He also uses Gloria Anzaldina's refiguring of a border as a wound and I think that Verrier's notion of primal wound might be referred to here as well.

Hartigan quotes Stephen Jones, the rugby writer, saying that most people regard the haka as 'politically correct lunacy'.

Hartigan offers an international perspective ad this is welcome. He talks about Matt Damon in Invictus and the haka and image of Jonah Lomu in that film.

He looks at the film Forever Strong of 2008 to good effect as well.

In an interesting way he sees the haka as a wananga of historical approach. This is perhaps inadvertently important as the meaning of wananga- and Hartigan does not explore this- is to worry at, to shake or shake up while the term haka also refers to stamping the feet, shaking the body and also to shaking hings up. Further aspects of the term are discussed later in this volume.

Hartigans use of terms throughout is effective and generally accurate. When he wants to be brief he says so as with the definition of Pakeha- New Zealanders of European ancestry. He quotes judiciously from a wide variety of writers including Hokowhitu (2004:270) or Bhapha with regard to chain of mimesis.

This sound scholarship is accompanied with a breadth of vision that takes considerations of dance and theatre well outside of this country and then brings it back to clear historical and social points in Aotearoa. To close with a quote from Hartigan that sets out his thinking;

'These productive contradictions signal the tensions in colonial discourses of assimilation even as the common thread of rugby seems to rehearse them. Pivotally, they demonstrate the impossibility of suturing the colonial wound and presenting the team as an emblem of postcolonial national unity. To refigure Joseph Roach's thoughts on racialized identities in Cities of the Dead, the haka rips apart surrogation (Roach 1996: 3-6). While surrogation relies on colonial 
discourses constructing the myth of the community's unified core identity, fulfilling 'a desire for the telos of perfect closure' (Roach 1996: 33), the haka falls awkwardly between the options of affirming or refuting the proximity of the performers in order to construct the myth of unity. In particular, the mere presence of Pakeha performers sabotages the folklorizing possibility of fixing the haka as a prepositional moment in a precolonial past. In these terms, the haka displays not unity but productive, problematic and challenging disunity. Displaying the disjunctures and liminalities at the heart of cultural formations undermines not only claims to a unified public but the contested temporalities that seek to foreclose colonial history.

Of course, the physical prowess of the team did not confound the colonial narrative so much as confirm it. Even if beaten on the pitch, the United Kingdom could still win discursively. The Times accommodated the praise of the Natives team by considering it be presented as the nonnormative actions of a counterpublic, attempting to stand outside and in opposition to a general public, its performance exceeds this model. By interweaving affect in the social structures of the public, the haka of 1888 exerts a gravitational pull, a temporal drag upon the haka of 2008. In Carolyn Dinshaw's terms, past bodies palpably connect with present ones, and relations with the past become material touchings upon contemporary bodies (Dinshaw 1999, Freeman 2005: 60). As a result, the present is rendered temporally porous. The past of 1888 , percolating in the shape of Pakeha players performing the haka alongside Maori players, acts as an obstacle to simple stabilizations of national identity. Subsequently, the haka's contradictions, problematics and challenges become a productive encumbrance. They serve as a demand to recognize the temporal operations of the colonial past upon the present and future, and as a performance, above all, that embarrasses.' 
The next article, Performing Mãori: Kapa Haka on the Stage and on the Ground, is by Sharon Mazer and was published in Popular Entertainment Studies (Vol. 2, Issue 1, pp. 41-53 in 2011). This work brings us back to mainstream Maori dance, to kapa haka and that has to be good and refreshing simply because a lot seems to be written about Maori contemporary dance.

Like Hartigan Mazer establishes a link between past and present and an attention to the significance of history. Kapa Haka 'acts back'. Mazer says that Kapa Haka is a formal performance practice arising at the intersection between ritual theatre and sport. She suggests that Kapa Haka is a signal part of the New Zealand identity, performance and practice.

Mazer also suggests that Kapa Haka performance evokes an idealisation of community as well as a redress for colonisation. Mazer resists inclusion;

'Community organisations and civic institutions add karanga (call), haka (dance) and waiata (song) into the start of events such as flower shows, arts festivals and citizenship ceremonies, events that have little to do with Māori culture and with few Māori present. Even at my own university, staff are now regularly invited to waiata practices and expected to be ready to perform in periodic powhiri (ritual welcome) for new staff and to join the singing at the start of European rituals such as orientations and graduations - although most of us, in avoiding these events as a rule, have managed to go a long time without learning our university's waiata as well.'

Without mentioning Marcuse Mazer seems to be talking about his concept of desublimation where classical music becomes muzak in lifts or something like this idea to talk about the way Kapa Haka is found everywhere in New Zealand including places where there are few Maoris. This goes through the essay and in a coda Mazer describes how strange she felt at the use of mihi and waiata by non- Maori at a ceremony at her university following an earthquake. This coda is actually a very important piece of writing and says a lot in a 
few words about identity and its assumption in Aotearoa/ $\mathrm{Nw}$ Zealand.

Mazer quotes King;

'Writing from a less explicitly polemic, Pākehā, perspective, historian Michael King describes post World War II New Zealand as a confrontation between two competing worldviews, or "myths": for Māori a renewed valuing of whakapapa and turangawaewae as centred on the marae, and for the Pākehā, "the matching myth was that New Zealand had the best race relations in the world, a verdict Pakeha politicians trumpeted at every possible opportunity.'

Mazer comes back again and again to confrontation with the Pakeha even though the great bulk of waiata and performance at Matatini is about topics of he day and these may not necessarily have a lot to do with Pakeha or confrontation with them;

'Retrieved from the elements of Māori ritual protocol and traditional performance practices, as part of a larger political movement, Kapa Haka is not in itself "ritual performance" although one might argue that as it stages the revival of Māori language and culture it ritualises Māori resistance to the dominant Pākehā culture.'

Mazer offers a very interesting and important consideration of the proscenium or archway between stage and audience. The stage is not a marae. It is a connection between past and present amongst other things. Mazer quotes Filewod and then goes on to suggest that the broken line between the pre-colonial past and the post- colonial present may be connected in performance.'

Mazer quotes Michael Warner in talking about a 'social totality' and like Hartigan she talks of a 'counter-public'.

In an interesting turn of phrase Mazer suggests that when Maori are rehearsing they are simultaneously practicing and memorialising being Maori'. As she does this Mazer refers to Diana Taylor's The Archive and the Repertoire: Performing Cultural Memory in the Americas. 
Mazer talks of aspects of hui in Kapa Haka and speaks of how groups recognise one another.

In an excellent discussion of the to and fro at Kapa Haka festivals where the audience haka at the stage Mazer suggests that the proscenium is a frame. She discusses utu and talks about the past being on stage and the present in the audience. While the analysis does not go into the kawa and processes of whakautu it does raise some very interesting points.

Another interesting recent article is. Linda Ashley's Culturally different dances in the New Zealand arts curriculum: Understanding about fusion, tradition and making dances in context (Koowhiti, tekahroa.com). Like Greenwood's thesis Linda Ashley's article is about dance education and there is an excellent discussion of fusion.

Linda Ashley's concern is to do with intercultural learning with special reference to fusion dance.

She sets out a set of questions and a methodology to go with that with a profile of a bicultural, culturally democratic and sustainable dance education in New Zealand.

Ashley uses questionnaires, focus groups and participant observation as a researcher. She provides a very thorough and very sound methodology and along with West would seem to have the best research practices in the set of papers reviewed.

Ashley draws on the dance education tradition of Laban (1960, 1988) and H'Doubler (1974) and talks of improvisation and creative dance.

Ashley brings the welcome perspective of Andre Grau (192) an anthropologist who cautions that a creative dance approach where there are unequal power elations may not be a good idea.

' A perspective of fluidity is required when considering cultural identity, in itself an arguably obsolete and passé concept in the postmodern world. Identity is especially pertinent to conceptualise individuals and cultural phenomena when reconstrued as multiple, or fused. It is, however, also recognised as in use in everyday public life "to 
understand the world we live in as well as imagine other worlds" (Grau, 2007, p. 203).'

Ashley also refers to Homi Bhapha (1994) and the third cultural space as well as Bahktin (1981) Ashley talks of 'building a sense of identity'.

Ashley notes the difficulties in understanding tradition and refers to the literature including Raymond Williams.

She mentions 'benign appropriation' as she talks about creative dance;

'In contextualising early modern dance ethnically as a Eurocentric art form, Joan Frosch (1999) identifies pioneers such as Isadora Duncan, Mikhail Fokine, Ruth St. Denis and Ted Shawn, because of their shared proclivity for the mis/appropriation and modern adaptations of the dances of other cultures.' (Ashley 2012: 210). As her argument proceeds Ashley notes some of the issues.

The idea of primitive dance is called into question.

She finds in her research that some respondents find that teaching about dance is scary as there is too much preparation involved. It is the Understanding Dance in Context strand known as the UC strand that is problematic for many teachers.

This discussion is made against the background of a need for a rewrite of arts achievement objectives. The UC strand runs across all art forms set out and is a very important counter to the creative dance approach:

'In curriculum terms, if creative dance in the DI strand remains separate from the UC strand it could become a hegemonic force, concealing and /or marginalising cultural differences in the process of making dance. I suggest that recognising all dance making as being culturally contextual could inform teaching about making culturally different dances, offer deserved recognition and support to the dancers of minority cultures, and contribute towards sustainability of the dances within educational settings and the dance world more generally. Ashey 2012: 112 
Teaching about dance is often done by guest specialists. The split between theory and practice is problematic for many teachers.

The issue is how to make theory culturally and historically meaningful in the context of the physical experience of dancing.

"Contemporary style is fine so long as you have a traditional base. Otherwise you are... without authority, without mana." (Valance Smith) (quoted in Ashley 2012: 124)

Ashley refers to Laban's terms known as the dance elements. She suggests that creative dance can become a hegemonic force concealing other approaches. Tanemahuta Gray's Taniwha Loong is considered as a better approach fusing Chinese Dragon Dance, Lion Dance and Shaolin martial arts with Maori wero, haka and taiaha.

'Contentions that could arise around what may be seen as inappropriate appropriation are articulated by British classical Indian dance artist, Nina Rajarni, who deliberately avoids fusion. She is concerned about the possible extinction of Indian classical dance via the ever-increasingly popular dilution with western dance vocabularies, and so she retains a strictly traditional movement vocabulary, contextualised in contemporary stories and costumes reminiscent at times of a Bollywood narrative. In resisting the modern movement interlopers, Rajarni states: "Fusion is not wrong, but it's wrong for me” (Winship, 2007).' (Ashley 2012: 213)

In a sense Kapa Haka is an example of what Ashley considers fusion dance. Say one said, for example, that around the time of the First World War haka and wero and the process of powhiri were added to concert party routines so there was an emphasis on lines and formations of dancers and music in the form of country and western tunes were added as well. How then might this be considered and evaluated?

There is an interesting aside from a Maori respondent saying 'things have freed up as at least you don't now need permission' (ibid i2012:127). Asides like this give a flavour to 
the general problem or issue which is about creativity and appropriate reflection;

'Understanding about the relationship between hybridity and tradition can be nuanced, and the question then arises how, in their daily teaching, teachers may implement the differences between western appropriation of others' dances or acculturation by others as they teach about fusion dance.' (ibid 2012: 129)

So here is a standoff between an immediate and unconsidered- or, at least, an inadequately considered response to stimulus and knowing the cultural context of a dance move. What is best practice?

Ashley looks closely at a mini syndicate model and concludes with a plea for empirical research as a matter of best practice.

A few words - certainly not a conclusion - at this point in the discussion.

Taken together this literature provides a corpus of wellarticulated and, in some cases, new thinking.

Any concluding comment to the work considered above would have to be selective as there is so much to consider.

One idea that comes to mind is struggle. Greenwood is involved in a struggle to sustain and develop Pakeaka in the face of institutional drag in the form of the Ministry of Education. This is a struggle for continued support.

Emma West's thesis can be considered as a struggle against the prevailing ideology, the false comfort of biculturalism, of having to be someone that she did not really have to be.

And Hartigan's essay may be seen as struggle with conventional ideas about the haka as found internationally amongst rugby writers.

Mazer's coda shows a struggle with the way institutions use indigenous arts and Ashley's work shows the struggle of making sure that dance is understood culturally. 
Then there are the words like 'embarrassment' in Hartigans writing about the haka, the feeling of 'cringe' in Mazer's Coda and he sense of unease in Ashley's work about dance not understood in cultural terms and the subversion of martial arts to become erotic invitations suggested by Hamilton about Mika's work.

All in all this is a curious, questioning and critical mix. In an abundance of queries and clichés there are so many doors opening, hares running and, at the same time, so many pauses for reflection in the work above.

All that said, that is about as far as this version of the literature review goes. At a later stage there may be a more exhaustive summary but the intention here has been to actually talk about what the literature says rather than to tell the writers what they are saying.

In closing it is important to stress the quality of the work involved. And also to talk of the courage of the writers. Some of the topics are unusual and some of the fieldwork is impressive as is the quality of research; that is research done and research supervised. As well as the performance of the writers in the field and at the desk there has obviously been some remarkable work done by mentors. 


\section{Bibliography}

Balme, Christopher (2007) Pacific Performances: Theatricality and cross-cultural encounter in the South Seas, London: Palgrave.

Bhabha, Homi (1994) 'Of mimicry and man: The ambivalence of colonial discourse', in The Location of Culture, London: Routledge.

Chow, Rey (2006) 'Sacrifice, mimesis and the theorizing of victimhood (A speculative essay)', Representations 94: 131-49.

Conquergood, Dwight (1995) 'Of caravans and carnivals: Performance Studies in motion', TDR 39(4): 137-41.

Dinshaw, Carolyn (1999) Getting Medieval: Sexualities and communities, pre- and postmodern, Durham, North Carolina: Duke University Press.

Eyton, Thomas (1896) Rugby Football Past and Present: The tour of the native team, Palmerston North: William Hart.

Falcous, Mark (2007) 'The decolonizing national imaginary: Promotional media constructions during the 2005 Lions tour of Aotearoa-New Zealand', Journalof Sports and Social Issues 31(4): 374-93.

Fish, Stanley (1997) 'Boutique multiculturalism, or Why liberals are incapable of thinking about hate speech', Critical Inquiry 23(2): 378-95.

Fletcher, John (2010) 'Sympathy for the devil: Nonprogressive activism and the limits of critical generosity', in Henry Bial and Scott Magelssen (eds) Theater Historiography: Critical Interventions, Ann Arbor: University of Michigan Press.

Freeman, Elizabeth (2005) 'Time binds, or Erotohistoriography', Social Text 23(3-4): 57-68.

Gardiner, Wira (2007 [2001]) Haka: A living tradition, 2nd edn, Auckland: Hodder Moa.

Hemmings, Clare. (2005) 'Invoking affect: Cultural theory and the ontological turn', Cultural Studies 19(5): 548-67.

Hokowhitu, Brendan (2004) 'Tackling Maori masculinity: A colonial genealogy of savagery and sport', The Contemporary Pacific 16(2): 259-84.

Jackson, Steven and Hokowhitu, Brendan (2002) 'Sport, tribes and technology: The New Zealand All Blacks haka and the politics of identity', Journal of Sport and Social Issues 26(2): 125-39.

Jones, Stephen (2010) 'All Blacks shouldn't make a song and dance about haka', The Times, 31 October.

Karetu, Timoti (1993) Haka! The dance of a noble people, Auckland: Reed.

Keating, Frank (2008) 'It's time the haka posture is put out to pasture', The Guardian, 18 November.

Mulholland, Malcolm (2009) Beneath the Maori Moon: An illustrated history of Maori rugby, Auckland: Huia.

Ridout, Nicholas (2006) Stage Fright, Animals and Other Theatrical Problems, Cambridge: Cambridge University Press.

Roach, Joseph (1996) Cities of the Dead: Circumatlantic performance, New York: Columbia University Press. 
Ryan, Greg (1993) Forerunners of the All Blacks: The 1888-9 New Zealand native football team in Britain, Australia and New Zealand, Christchurch: University of Canterbury Press.

Warner, Michael (2002) Publics and Counterpublics, New York: Zone Books.

Werry, Margaret (2005) “The Greatest Show on Earth": Political spectacle, spectacular politics and the American Pacific', Theatre Journal 57(3): 355-82.

Zavos, Spiro (1998) Ka Mate! Ka Mate! New Zealand's conquest of British rugby, Auckland: Viking. 